\title{
Open Government Data Sebagai Inisiatif Anti-korupsi di Indonesia: A Cross- Country Comparison
}

\author{
Darusalam $^{1}$, Dhata Praditya ${ }^{2}$ \\ d.darusalam@tudelft.nl ${ }^{1}$, d.praditya@tudelft.nl ${ }^{2}$ \\ ${ }^{1}$ Prodi Sistem Informasi, Fakultas Sains dan Teknologi, UIN Raden Fatah Palembang \\ ${ }^{2}$ Kandidat Ph.D, Technology University of Delft, Netherlands
}

Diterima: 20 Februari 2017 | Direvisi: 13 Maret 2017 | Disetujui: 20 April 2017

(C) 2017 Program Studi Sistem Informasi Fakultas Sains dan Teknologi,

Universitas Islam Negeri Raden Fatah Palembang, Indonesia

\begin{abstract}
Abstrak: Korupsi masih menjadi salah satu permasalahan utama di Indonesia. Sudah banyak upaya yang dilakukan dalam rangka mengurangi kerugian negara yang diakibatkan oleh korupsi. Diantaranya adalah penggunakan teknologi, dalam hal ini teknologi informasi dan komunikasi, sebagai alat untuk memfasilitasi keterbukaan informasi oleh pemerintah. Penelitian ini akan menganalisa implementasi open data sebagai salah satu alternatif untuk mendeteksi dan mengurangi korupsi di Indonesia, mulai dari level pemerintahan daerah hingga pemerintah pusat. Dengan mengambil studi perbandingan dengan implementasi di beberapa negara sebagai rujukan, hasil dari penelitian ini menunjukkan bahwa adopsi open data dapat meningkatkan transparansi publik, dan mengurangi korupsi.
\end{abstract}

Kata Kunci: Open Data Government (OGD), Korupsi, Transparansi

\begin{abstract}
A corruption remains one of the major problems in Indonesia. There have been many efforts made in order to reduce caused by corruption. Among them is the use of technology, in this case information communication and technology (ICT), as a tool to facilitate the disclosure of information by the government. This study will analyze the implementation of open data as an alternative to detect and reduce corruption in Indonesia, ranging from local government level to the central government. Using a comparative study from open data implementation in two countries as references, the results from this study indicate that adoption of open data increase public transparency and reduce corruption. Keywords: Open Data Government (OGD), Corruption, Transparansy
\end{abstract}

\section{PENDAHULUAN}

Tindak kejahatan korupsi menurut Undang-Undang Nomor 31 tahun 1999 jo UndangUndang 20 Tahun tentang Pemberantasan Tindak Pidana Korupsi meliputi kerugian negara berupa materi dan non-materi seperti menyalahgunakan kewenangan, penyuapan, pengelapan dalam jabatan, pemerasan dalam jabatan, pemborosan dan gratifikasi. Korupsi merupakan salah satu permasalahan yang menjadi topik hangat untuk diperbincangkan di Indonesia. Sejak tahun 1998 Indonesia telah membuat berbagai reformasi untuk anti-korupsi, akan tetapi reformasi ini masih dinilai tidak sukses untuk mengurangi dan mendeteksi korupsi di Indonesia. Banyak usaha yang dilakukan pemerintah untuk memberantas korupsi di Indonesia, mulai dari penegakan hukum seperti pencegahan (preventif), misalnya dengan memberikan edukasi ke masyarakat dan edukasi pada lembaga swadaya masyarakat. Serta penindakan (kuratif), misalnya melalui pembentukan lembaga ad-hoc bernama KPK. Namun usaha yang dilakukan masih dinilai kurang memuaskan dan tidak memiliki desain strategi yang jelas, sehingga dalam beberapa hal tidak dapat mengurangi tindakan korupsi secara signifikan, dan korupsi terus berkembang (Kurniawan, 2009). Menurut (Bramastyo, 2014) "Korupsi di 
Indonesia dianggap sudah berada pada kondisi yang sangat genting. Data dan fakta tentang korupsi menunjukkan bahwa korupsi sudah begitu menggurita diseluruh sendi kehidupan bangsa Indonesia."

Menurut (Hardjaloka, 2014), pada tahun 2013 survey yang dilakukan oleh Corruption Perception Index berkenan dengan keterlibatan korupsi pada suatu Negara yang di teliti oleh Transparancy International (IT), secara interntional terdapat 6 negara yang memiliki tingkat Korupsi paling rendah dari 175 Negara yang dilakukan survey, diantaranya adalah, Denmark, Finlandia, Selandia Baru, Swedia, Norwegia, dan Singapura. Sedangkan pada tahun 2013 Indonesia menduduki peringkat 144, tetapi pada tahun 2016 Indonesia telah menduduki peringkat 90 dari 176 Negara (ICW, Trend Pemberantasan Korupsi 2014. Retrieved from Jakarta: Index, C. P. (2010). Transparency International, 2014).

Dalam UU No.3 Tahun 1999 jo. UU No.20 Tahun 2001, telah dirumuskan tiga puluh bentuk tindak pidana korupsi (Handbook, 2006). Ketiga puluh bentuk dari tindak pidana korupsi ini dikategorikan menjadi tujuh kelompok yaitu: 1) Kerugian keuangan negara, 2) Suap-menyuap, 3) Pengelapan dalam jabatan, 4) Pemerasan, 5) Perbuatan curang, 6) Benturan kepentingan dalam pengadaan dan 7) Gratifikasi. Jenis lain yang berhubungan dengan tindak pidana korupsi menurut (Komisi Pemberantasan Korupsi, 2006), yaitu, a) Merintangi proses pemeriksaan perkara korupsi, b) Tidak memberikan keterangan atau memberi keterangan yang tidak benar, c) Bank yang tidak memberikan keterangan rekening tersangka, d) Saksi atau ahli yang tidak memberi keterangan atau memberi keterangan palsu e) Orang yang memegang rahasia jabatan tidak memberikan keterangan atau memberi keterangan palsu dan f) Saksi yang membuka identitas pelapor.

Tabel 1: Trend Pemberantasan Korupsi di Indonesia

\begin{tabular}{lccccc}
\hline & 2010 & 2011 & 2012 & 2013 & 2014 \\
\hline Jumlah Kasus & 448 & 436 & 401 & 560 & 629 \\
$\begin{array}{l}\text { Kerugian Negara } \\
\text { (dalam triliun }\end{array}$ & 3.3 & 2.1 & 10.4 & 7.3 & 5.3 \\
$\begin{array}{l}\text { rupiah) } \\
\text { Jumlah Tersangka }\end{array}$ & 1157 & 1053 & 877 & 1271 & 1328
\end{tabular}

Sumber: (ICW, Trend Pemberantasan Korupsi, 2013) \& (ICW, Trend Pemberantasan

Korupsi 2014. Retrieved from Jakarta: Index, C. P. (2010). Transparency International, 2014)

Dari Tabel 1 diatas, dapat dilihat bahwa pemberantasan korupsi sejak 2010 menunjukkan peningkatan dari sisi kualitas dan kuantitas. Namun disisi lain, data diatas juga dapat diartikan bahwa dari tahun ke tahun korupsi tidak juga berkurang, malah menunjukkan peningkatan. Sementara untuk tahun 2015, "KPK melakukan penyelidikan 84 perkara, penyidikan 50 perkara, penuntutan 58 perkara, inkracht 32 perkara, dan eksekusi 33 perkara." (Portal pengetahuan anti korupsi, 2015).

Lebih lanjut, dari Gambar 1 berikut, diperlihatkan sektor mana saja yang rentan untuk dijadikan "bancakan" para koruptor. Dari data Indonesia Corruption Watch tahun 2013 dan 2014, sektor infrastruktur, keuangan daerah dan pendidikan merupakan tiga besar sektor paling rawan korupsi, dengan masing-masing 380, 282, dan 131 kasus. 


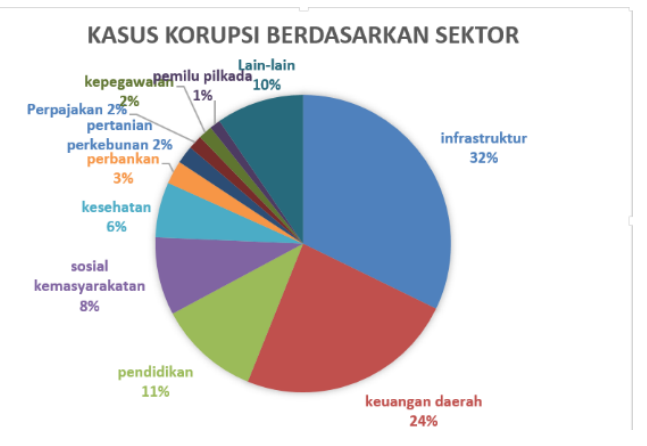

Gambar 1 Korupsi Berdasarkan Sector

Sumber: (ICW, Trend Pemberantasan Korupsi, 2013) \& (ICW, Trend Pemberantasan Korupsi 2014. Retrieved from Jakarta: Index, C. P. (2010). Transparency International, 2014)

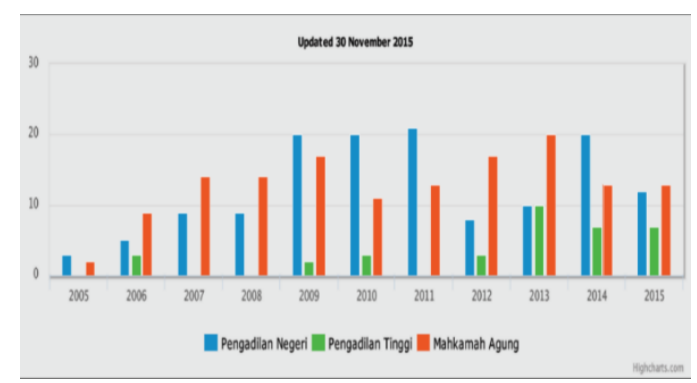

\section{Gambar 2 Rekapitulasi Penindakan Pidana Korupsi di Indonesia} (Anonim, 2015)

Disisi lain, dari Gambar 2 diatas, kasus korupsi yang ditangani oleh Pengadilan Negeri lebih mendominasi jika dibandingkan dengan kasus korupsi yang di tangani oleh Pengadilan Tinggi dan Mahkamah Agung. Pada tahun 2015, Mahkamah Agung melakukan penyelidikan hampir 12\% kasus korupsi, $11 \%$ penyelidikan di Pengadilan Negeri dan 8\% di Pengadilan Tinggi.

Jika dibandingkan dengan negara lain, maka Indonesia memiliki ranking yang cukup buruk untuk penanganan korupsi. Data kuantitatif yang dihasilkan dari survey oleh beberapa lembaga independen menunjukkan kenyataan yang memprihatinkan. Negara yang mempunyai Indeks Prestatasi Komulatif tertinggi dimiliki oleh Denmark, Selandia Baru dan Singapura. Masing-masing negara meraih IPK 9,3. Sedangkan negara yang tingkat korupsi tertinggi atau terkorup adalah Somalia dengan nilai (IPK 1,1), kemudian Myanmar (IPK 1,4), Afghanistan (IPK 1,4). SementaraIndonesia berada pada tingkat ke-5 untuk ukuran Asia Tenggara dengan (IPK 3,5), berada dibawah Thailand (IPK 3,5), Malaysia (IPK 4,4) Brunei Darussalam (IPK 5,5) dan Singapura (IPK 9,3) (Kurniawan, 2011).

\section{Open Data - Good Governance}

Pada tahun 2012, beberapa lembaga swadaya masyarakat yang berfokus pada pembangunan good governance, seperti ICW, Kontras, IPC, IBC dan lain-lain sempat membuat sebuah laporan independen implementasi Open Government Partnership di Indonesia. Latar belakang dari dibuatnya laporan independen tersebut adalah sebagai inisiatif untuk mendorong keterbukaan informasi public dalam rangka menjalankan UU No.14/2008 tentang Keterbukaan Informasi Publik. Dalam undang-undang ini disebutkan adanya jaminan hukum bagi masyarakat dalam meminta informasi dari lembaga publik. 
E-government merujuk kepada penggunaan teknologi seperti internet dan teknologi komuniskasi serta website dalam menyelengarakan pelayanan pemerintah secara elektronik kepada masyarkat, dunia usaha, organisasi, dan lain sebagainya (Hardjaloka, 2014).

Salah satu cara media membuka informasi ke public adalah dengan mengunakan TIK (Teknologi Informasi dan Komunikasi). Menurut Chaftield yang dikutip oleh Veenstra (2012), TIK adalah salah satu media kunci untuk membuka informasi ke publik. Dengan keterbukaan informasi, publik atau masyarakat dapat mengakses beragam informasi tentang urusan-urusan publik yang berkaitan dengan lembaga pemerintah (Janssen, 2012). Keterbukaan informasi ke publik ini disebut "open data". Menurut (Jetzek, T., Avital, M., \& Bjorn-Andersen, N., 2014) definisi open data adalah "data which can be freely accessed on the Internet, without restriction to re-use, available with authorization access that allow the data to be re-use without limitation, including across different fields of endeavor". Definisi lain tentang open data oleh Kucera and Chlapek (2014) adalah penyebaran informasi dari organisasi swasta dan pemerintah sehingga setiap orang bisa melihat secara bebas, mengunakan dan menginformasikan ke orang lain. Ada beberapa keuntungan dari open data bagi pemerintah diantaranya adalah meningkatkan akuntabilitas (Janssen, M., Charalabidis, Y., \& Zuiderwijk, A., 2012), mendorong transparansi dan mengurangi korupsi (Matheus, R., Ribeiro, M. M., Vaz, J. S., \& Souza, C., 2010), meningkatkan kepercayaan dan partisipasi masyarakat (Kassen, 2013), dan mendorong efisiensi khususnya disisi pelayanan masyarakat (Badri, M. A., \& Alshareb, K., 2008). Pemerintah Indonesia sendiri sudah memulai untuk menerapkan open data sejak tahun 2010, sesuai dengan dasar hukum yang telah diterbitkan dengan undangundang No. 14/2008 mengenai keterbukaan informasi publik. Kemudian undang-undang ini dilanjutkan dalam peraturan pemerintah melalui PP No. 61/2010.

Tujuan utama dari inisiatif open government data pada dasarnya adalah terciptanya good governance pada lembaga publik di Indonesia. Soelendro 2000 di dalam (Sadjiarto, 2000) salah satu unsur utama untuk mewujudkan good governance adalah transparency, fairness, responsibility dan accountability. Sementara itu, Hadari Yunus 2000 di dalam (Sadjiarto, 2000) juga membahas unsur dari good governance yaitu: tuntunan keterbukaan (transparency), peningkatan efisiensi di segala bidang (efficiency), bertanggung jawab (responsibility) dan kewajaran (fairness).

Menurut (Matheus, R., Ribeiro, M. M., Vaz, J. S., \& Souza, C., 2012), transparansi adalah keterbukaan dari informasi yang masuk, bebas di akses dan bisa diakses secara menyeluruh, diperbaharui secara berkala, diupload di sebuah portal khusus yang bisa melibatkan masyarakat untuk berkomunikasi dan berinteraksi dengan fitur-fitur yang tersedia, sehingga bisa membantu masyarakat untuk mencari informasi apa saja yang mereka inginkan. Sedangkan akuntabilitas menurut (Janssen, 2015) adalah jawaban atau bukti dari suatu kegiatan untuk pertangungjawaban dari suatu konsekuensi. Definisi tentang akuntabilitas juga diberikan oleh Mardiasmo (2009) yaitu pertanggung jawaban kepada publik atas setiap aktivitas yang dilakukan. Fairness menurut Woods (1999) terdiri dari dua aspek yaitu prosedural dan substantif. Prosedural membutuhkan proses representasi, pengambilan keputusan dan penegakan hukum harus jelas ditentukan sebelumnya, tidak memihak, terdiri dari beberapa pilihan dan konsisten. Disisi lain substantif terkait bagaimana menjaga hasil dari sebuah institusi dapat adil dan bagaimana mengatur distribusi kekuasaan, pengaruh dan sumber daya dalam institusi tersebut.

Lebih lanjut, karakteristik good governance menurut Mardiasmo (2009), yaitu: a) Participation, atau keterlibatan masyarakat dalam membuat keputusan baik secara langsung maupun melalui lembaga perwakilan yang dapat menyalurkan aspirasinya, b) Roles of law, yaitu kerangka hukum yang adil dan dilaksanakan tanpa pandang bulu, c) Transparency, yaitu transparansi dibangun atas dasar kebebasan dalam memperoleh informasi, d) Responsiveness, yaitu lembaga-lembaga publik harus cepat dan tanggap dalam melayani stakeholder, e) Concensus orientation, yaitu berorientasi pada kepentingan masyarakat yang lebih luas, $\mathrm{f}$ ) Equity, setiap masyarakat memperoleh kesempatan yang sama untuk memperoleh kesejahteraan dan keadilan, g) Efficiency dan Effectiveness, yaitu: pengelolaan sumber daya 
publik dilakukan secara berdaya guna (efisien) dan berhasil guna (efektif), h) Accountability, yaitu: pertanggung jawaban kepada public atas setiap aktivitas yang dilakukan dan i) Strategic Vision, yaitu: penyelengaraan pemerintahan dan masyarakat harus memiliki visi jauh ke depan. Untuk mewujudkan karakteristik-karakteristik dari good governance diatas perlu dilakukan reformasi kelembagaan (Institutional reform) dan reformasi manajemen publik (public management reform) (Mardiasmo, 2009)

Dari latar belakang diatas, maka tulisan ini akan membahas bagaimana open data bisa memberikan solusi untuk memberantas tindak pidana korupsi di Negara Indonesia sehingga bisa menciptakan good governance. Artikel ini akan membahas bagaimana implementasi open government data dapat menjadi salah satu alternative solusi dalam upaya pemberantasan tindak pidana korupsi di Indonesia. Untuk menjelaskan hal tersebut, pembelajaran dari keberhasilan implementasi system OPEN di Korsel dan monitoring sistem Brazil menjadi bahan rujukan.

Struktur artikel ini adalah sebagai berikut: bagian kedua dari artikel akan memaparkan landasan teori terkait penyebab korupsi. Dilanjutkan dengan penjelasan tentang metodologi yang digunakan dalam riset ini. Terakhir hasil studi banding akan didiskusikan, berikut penjelasan faktor-faktor penting yang harus dilakukan sehingga implementasi berhasil. Sehingga harapannya Indonesia juga bisa menerapakan open data sebagai salah satu alat untuk memerangi tindak pidana korupsi yang sekarang ini marak berkembang.

\section{METODOLOGI PENELITIAN}

Tinjauan pustaka atau literature review adalah salah satu elemen penting untuk penelitian dan umumnya fokus sebagai dasar dalam proyek penelitian (Dwivedi, Y. K., Ravishankar, M. N., \& Simintiras, A. C., 2015). (Levy, Y. \& Ellis, T., 2006) menyatakan bahwa penelliti pemula menggunakan metode tinjauan pustaka sebagai pengelompokan beberapa jurnal dan ringkasan atau mengkolaborasikan dengan beberapa naskah penelitian yang kemudian dijelaskan kepustakaannya. Definisi kajian literatur review untuk berbagai peneliti yang menyebutkan "penggunaan ide-ide dalam literatur untuk membenarkan pendekatan khusus pada topik tertentu, pemilihan metode, dan demonstrasi bahwa penelitian ini memberikan kontribusi sesuatu yang baru" (Hart dikutip dalam Levy dan Ellis, 2006). Hart (1998) juga mencatat bahwa untuk tinjauan pustaka, "kualitas disesuaikan dengan luas dan kedalaman, ketelitian dan konsistensi, kejelasan dan keringkasan dan analisis yang efektif dan sintesis" (dikutip dalam Levy dan Ellis, 2006). (Levy, Y. \& Ellis, T., 2006) melaporkan studi J.Shaw, menekankan aspek tinjauan pustaka harus "menjelaskan bagaimana salah satu bagian dari penelitian dibangun di atas yang lain". Serta Webster dan Watson 2002 dikutip dari Levy dan Ellis (2006) memberikan definisi tinjauan pustaka sebagai salah satu yang "menciptakan dasar yang kuat untuk memajukan pengetahuan. Dengan memfasilitasi pengembangan teori, menutup daerah di mana sejumlah besar penelitian ada, dan mengungkapkan daerah dimana penelitian diperlukan". Kemudian (Levy, Y. \& Ellis, T., 2006), menyatakan tinjauan pustaka yang efektif harus mencakup beberapa yaitu: a) methodologically analyze and synthesize quality literature, b) provide a firm foundation to a research topic, c) provide a firm foundation to the selection of research methodology, and d) demonstrate that the proposed research contributes something new to the overall body of knowledge or advances the research field's knowledge-base.

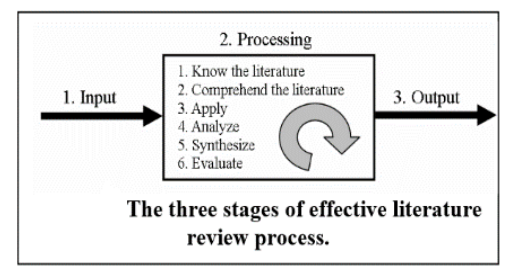

Gambar 3 Tiga tahapan literature review proses Sumber: (Levy, Y. \& Ellis, T., 2006) 
Gambar 3 menjelaskan tiga proses untuk mendapatkan literature review yang efektif. Jurnal ini akan mengggunakan literature review sebagai metodologi untuk mengumpulkan data dan informasi tentang open data yang memberikan kontribusi yang positive dalam memerangi korupsi diberbagai negara. Jurnal ini akan memaparkan contoh penerapan open data untuk memberantas korupsi di beberapa negara seperti Brazil, Korea, India dan Chile. Data-data dikumpulkan dari berbagai jurnal seperti, public admnistrasi jurnal, information system jurnal, economic journal, government journal dan lain-lain.

\subsection{Penyebab Korupsi}

Selain jenis-jenis korupsi yang di paparkan di latar belakang diatas, ada beberapa pakar membuat kategori dari korupsi. Menurut Jayawickrama 1998 \& Feng 2004 dikutip oleh (Kurniawan, 2009) korupsi dapat dibagi ke dalam dua jenis yaitu petty corruption (korupsi kecil) dan grand corruption (korupsi besar). Kemudian ditambahkan oleh Warren 2004 yang dikutip oleh (Kurniawan, 2009) membagi katagori pelaku korupsi menjadi enam katagori yaitu korupsi yang dilakukan oleh negara terdiri dari (korupsi eksekutif, korupsi peradilan dan korupsi legislatif), karupsi yang dilakukan oleh ranah pablik (media dan lembaga pembentuk opini publik lainya), korupsi yang dilakukan masyarakat sipil dan korupsi yang dilakukan oleh pasar. Penyebab korupsi sendiri menurut Tanzi 1998 dikutip oleh Kurniawan (2011) ada dua yaitu penyebab langsung dan tidak langsung. Penyebab langsung misalnya (pengaturan dan otorisasi; perpajakan; kebijakan pengeluaran/anggaran; penyedia barang dan jasa dibawah harga pasar; kebijakan diskresi lainnya dan pembiayaan partai politik. Penyebab tidak langsung yaitu: kualitas birokrasi; besaran gaji dan sektor publik; sistem hukuman; pengawasan institusi; transparansi, aturan, hukum dan proses dan teladan dari pemerintah. Selain itu ditambahkan oleh Nas, Price dan Weber 1986 yang dikutip oleh Kurniawan (2011), korupsi dilihat dari karakteristik individual terjadi ketika seorang individu itu serakah atau tidak bisa menahan godaan, lemah dan tidak memiliki etika seorang pejabat publik, dan korupsi dari sisi struktural yaitu birokrasi atau organisasi yang gagal, kualitas keterlibatan masyarakat dan keserasian sitem hukum dengan permintaan masyarakat. Bull \& Newell 2003 dikutip pada jurnal yang sama juga menyampaikan penyebab lain dari korupsi adalah budaya politik, struktur dan institusi politik, sistem kepartaian, partai pemerintah, partai politik, politisi dan ekonomi politik antara sektor publik dan sektor privat. Jadi, menurut Snape 1999 dikutip oleh Kurniawan (2011) ada tiga faktor yang menjadi penyebab utama berkembangnya korupsi, kolusi dan nepotisme di Indonesia yaitu faktor politik, faktor ekonomi, faktor budaya jawa.

Beberapa faktor penyebab tingginya tingkat korupsi di Indonsia adalah:

1. Rendahnya pemahaman terhadap arti penting dan strategisnya penerapan prinsip-prinsip GCG oleh pelaku bisnis di Indonesia. Selain itu, budaya organisasi turut mempengaruhi penerapan GCG di Indonesia (Kaihatu, 2006).

2. Pemerintah sebagai pelayan masyarakat memiliki kekuatan monopoli yang besar atas warga, tingkat diskresi yang besar, dan lemanya akuntabilitas pada pemerintahan (Hardjaloka, 2014).

3. Adanya diskresi (wewenang) yang dimiliki oleh pejabat publik yang bisa membuka peluang untuk disalahgunakan melakukan korupsi seperti adanya pungutan liar dalam pengurusan perizinan. Hal ini terjadi dikarenakan adanya prosedur yang kompleks dan proses yang panjang sehingga membuat masyarakat cenderung mengambil jalan pntas (Hardjaloka, 2014).

4. Minimnya akuntabilitas dapat terlihat dari cara pengambilan keputusan dan tindakan yang dilakukan oleh pejabat publik dan hal tersebut dapat diatas melalui teknologi informasi dan komunikasi. Ada tiga jenis akuntabilits 1). Partisipasi warga dalam proses politik dan pemerintahan, 2). Birokrasi yang efektif dan 3). Implementasi peraturan perundangundangan (Hardjaloka, 2014). 
Pendapat lain mengenai penyebab korupsi dapat dilihat dari tulisan Bull dan Newell (2003) dalam kaitannya dengan korupsi politik. Mereka membagi penyebab korupsi ke dalam empat faktor yang dianggapdapat mewakili faktor-faktor penyebab langsungmaupun faktor yang memfasilitasi tumbuhnya korupsiyakni faktor sejarah, struktur dan budaya. Keempat faktor penyebab korupsi menurut Bull dan Newell adalah (1) budaya politik; (2) struktur dan institusi politik; (3) sistem kepartaian, partai pemerintah, partai politik, dan politisi; serta (4) ekonomi politik antara sektor publik dan sektor privat.

Sementara itu, dalam pandangan (Shah, 2007) terjadinya korupsi di sektor publik akan sangat tergantung kepada sejumlah faktor yakni (1) kualitas manajemen sektor publik; (2) sifat alamiah (kondisi) hubungan akuntabilitas antara pemerintah dan masyarakat; (3) kerangka hukum; serta (4) tingkatan proses sector publik dilengkapi dengan transparansi dan diseminasi informasi. Upaya mengatasi korupsi tanpa mempertimbangkan keempat faktor ini menurut Shah akan menyebabkan ha sil yang kurang mendalam dan tidak berkelanjutan.

Pada kasus Indonesia sendiri, terdapat sejumlah analisis yang mencoba untuk menjelaskan mengapa korupsi begitu berkembang di Indonesia. Salah satuanalisis tersebut adalah sebagaimana diungkapkan Snape (1999). Menurut Snape, setidaknya ada tiga faktor yang disinyalir menjadi sebab berkembangnya korupsi, kolusi dan nepotisme (KKN) di Indonesia,yakni faktor politik, faktor ekonomi, dan faktor udaya Jawa (Kurniawan, 2011). Kemudian menurut (Kurniawan, 2011) Pusat Kajian Anti Korupsi FH UGM pada tahun 2010 yang menyatakan bahwa dari 103 orang pelaku korupsi, 43 diantaranya adalah adalah pejabat daerah. Dan menutup tahun 2010 pada triwulan IV (Oktober-Desember), pejabat daerah kembali berada di urutan teratas aktor korupsi sebanyak 124 orang. Di bawahnya diikuti oleh para legislator sebanyak 118 orang dan kalangan swasta sebanyak 33 orang ( www.pukat.hukum.ugm.ac.id). Pada tahun 2010 Komisi Pemberantasan Korupsi (KPK) menyebutkan bahwa sebanyak 73 persen perkara yang ditangani adalah korupsi di daerah (KPK, 2010). Data itu menunjukkan bahwa seiring pelaksanaan otonomi daerah, terjadi peningkatan angka korupsi di daerah. Dengan demikian semakin luasnya pelaksanaan otonomi daerah, perlu diimbangi dengan pengawasan yang memadai agar tidak menimbulkan korupsi, kolusi, nepotisme (KKN) baru atau memindahkan KKN dari tingkat pusat ke daerah.

Sedangkan menurut Andvig and Moene (1990) mengapa korupsi terjadi karena adanya kerja tim antara penyuap dan yang disuap. penulis memberikan alasan mengapa harus ada koneksi antara efektivitas korupsi serta mengapa frekuensi koruptor terus berkembang. Penulis juga menyebutkan ketika seorang pejabat korup dan meminta suap dan kedua pemohon memiliki kesempatan untuk menerima atau menolak tindakan ini dengan melaporkan actor yang mau disuap ke atasanya yang lebih tinggi. Selanjutnya, Andvig dan Moene (1990) menggambarkan korupsi di organisasi publik adalah ketika seorang melakukan tindakan langsung atau tidak langsung dengan memanfaatkan sumber daya organisasi, informasi khusus dan memanfaatkan pembuat keputusan untuk mendapatkan keuntungan dan tindakan terhadap aturan organisasi atau hukum pemerintah. Sebab lain menurut Andvig and Moene (1990) adalah di negara-negara berkembang yang dipaksa untuk memotong pengeluaran publik untuk mendapatkan neraca pembayaran yang seimbang oleh pemerintah. Masalah ini dapat mempengaruhi pemotongan pembayaran gaji dari pegawai negeri sipil melebihi orang-orang yang bekerja di sektor swasta dan dari masalah ini dapat meningkatkan kasus korupsi.

Selain itu Bac (2001) mengatakan korupsi terjadi karena adanya "media" yang menjembatani antara penyuap dan yang disuap atau seseorang yang mengambil keuntungan dari kekuasaanya sebagai pembuat keputsan. Selaian itu, tidak adanya transparansi di pemerintahan merupakan salah satu faktor lain yan sangat mempengaruhi adanya korupsi di organisasi tersebut. Walaupun faktanya menurut Bac (2001), dengan adanya transparansi tidak menjamin korupsi itu bisa secara otomatis bisa dikurangi. Walaupun korupsi lebih mungkin untuk dideteksi dalam organisasi yang lebih transparan, efek samping yang tak terelakkan adalah adanya potensi koruptor untuk menerima informasi yang lebih baik tentang dengan 
siapa mereka harus terhubung. Di sisis lain proses pendeteksian tindak pidana korupsi di Indonesia yaitu dengan cara melakukan penyelidikan terhadap institusi, organisasi atau individu yang dicurigai melakukan tindak pidana korupsi. Menurut Bramastyo (2014) "ketika terdapat potensi terjadinya korupsi maka penyidik yang ingin memperoleh bukti melakukan koordinasi dengan instansi terkait guna menindaklanjuti pelaporan tersebut. Instansi tersebut dapat berasal dari pegawai interen maupun lembaga pengawas keuangan yang memiliki kewenangan melakukan pengawasan khususnya melakukan audit terhadap keuangan pemerintah".

\section{HASIL DAN PEMBAHASAN}

Pada bagian pembahasa penulis akan memaparkan dua negara yang telah berhasil menerapkan OGD (open governement data) seperti di Soul South, Korea dan Brazil.

\subsection{Open Government Data di Seoul, South Korea}

Sebelum adanya sistem OPEN pemerintah daerah Seoul memiliki masalah korupsi yang serius. Masyarakat yang meminta layanan ke pemerintah melalui surat permohonan harus menunggu berminggu-minggu atau mungkin berbulan-bulan untuk mendapatkan hasil dari permohonan mereka. Untuk membuat proses aplikasi ini lebih singkat, beberapa dari warga Seoul memberikan "Express Fee" untuk pejabat yang menangani atau yang bertangung jawab atas permohonan mereka. Pejabat public di izinkan untuk memberikan "layanan cepat" untuk warga yang memberikan "Express Fee" (Shim \& Eom, 2008). Pada tahun 1998, walikota Seoul berinisiatif membuat program anti-korupsi dengan nama OPEN (the online procedures enhancement for civil application), dimana organisasi pemerintah membuka aturan-aturan kepada masyarakat Korea Selatan. Sistem OPEN ini dapat mengurangi korupsi dengan cara mengurangi human intervention dengan sistem informasi yang terdepan (Shim \& Eom, 2008), seperti yang diperlihatkan pada gambar 4 di bawah ini. Seluruh proses pengajuan lisensi maupun aplikasi dilakukan melalui online system, mulai dari registrasi user, registrasi layanan, sampai monitor progress layanan. Dari sisi organisasi pemerintah, dengan cara seperti ini, pengukuran kinerja pun menjadi lebih baik, dan dapat segera terindikasi di bagian mana proses yang memakan waktu lebih lama dari seharusnya, sehingga dapat segera dilakukan pembenahan

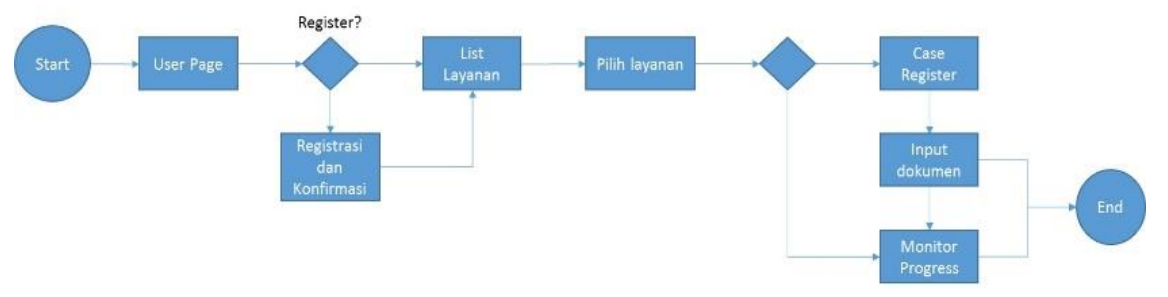

Gambar 4 Bagan proses OPEN dari sudut pandang pengguna

Menurut (APDIP e-note8, 2006) ada 4000 pegawai di 485 departemen di berbagai distrik di Seoul yang dilatih oleh pemerintah untuk mengoperasikan sistem OPEN ini. Dimana para pegawai tersebut bias menambahkan data atau merubah data-datanya. Dalam training tersebut para pegawai disediakan username dan password untuk masuk ke sistem tersebut dan setiap pegawai harus memasukan data-data disetiap department mereka. Menurut (Bhatnagar, 2003) sistem OPEN ini memberikan informasi kepada pengguna tentang panduan untuk anti-korupsi, sistem ini menampilkan indeks anti korupsi pada lima layanan yang dianggap paling rentan untuk terjadinya korupsi. System ini memberikan layanan informasi kepada masyarakat tentang aturan-aturan dan prosedur-prosedur dan memungkinkan "real-time monitoring" dari kemajuan aplikasi ini untuk izin dan lisensi. Pada akhir tahun 2000, jumlah pengunjung ke 
situs OPEN ini mencapai 2,6 juta. Untuk mendorong penggunaan yang lebih banyak sistem ini dibuat untuk bisa diakses melalui telepon seluler pada tahun 2001.

Sistem OPEN telah dievaluasi dengan cara yang berbeda. Hasil survey dari 1.245 warga membuktikan bahwa $85 \%$ percaya bahwa OPEN bisa membuat pemerintah Korea Selatan lebih transparan. Survey lain yang dilakukan oleh "South Korean chapter of transparency International" pada tahun 2000 dan 2001 menunjukan minat yang lebih baik pada sistem OPEN ini, akan tetapi terjadi penurunan kepuasan sekitar 7 kali pada system ini. Dikarenakan sistem ini pandang kurang perbaikan dalam hal tranparansi dan anti-korupsi dari tahun sebelumnya.

Tabel 2 Efek dari sistem OPEN pada Korupsi di Korea (Kim, Kim, \& Lee, 2009) Anti-corruption index

\begin{tabular}{lllllllll}
\hline Yearjindex & 1999 & 2000 & 2001 & 2002 & 2003 & 2004 & 2005 & 2006 \\
\hline Anti-corruption Index(SMG) & 64.0 & 683 & 70.4 & 71.5 & 77.1 & 82.9 & & 84.9 \\
Integrity assessment (KICAC) & & & & 6.43 & 7.71 & 8.38 & 8.68 & 8.77 \\
$\begin{array}{l}\text { Corruption Perceptions Index } \\
\text { (Transparency International) }\end{array}$ & $3.8(50 / 99)$ & $4.0(48 / 90)$ & $4.2(42 / 91)$ & $4.5(40 / 102)$ & $4.3(50 / 133)$ & $4.5(47 / 146)$ & $5.0(40 / 159)$ & $5.1(42 / 163)$ \\
\hline
\end{tabular}

Source: Korea Independent Commission against Corruption. 2007. The Integrity Assessment Report. The anti-corruption index, available at www.seoul.g0,kr.

Berdasarkan Tabel 2 diatas, ketika OPEN diperkenalkan pada tahun 1999 anti korupsi indeks dari Seoul Metropolitan Government (SMG) adalah 64,0. Meningkat menjadi 84,9 pada tahun 2006. Penilaian dilakukan oleh "Korea Independent Commision against Corruption (KICAC)". Akan tetapi, ada dua alasan yang mungkin membuat OPEN sistem menjadi bermasalah dalam hal penurunan efek langsung pada tingkat korupsi urusan sipil. Pertama, Indeks anti korupsi di umumkan oleh SMG sendiri, dengan demikian kemungkinan ada masalah dalam hal reliabilitas data. Kedua, indeks persepsi korupsi diumumkan oleh Transparency International, dan menunjukan bahwa tingkat korupsi di pemerintah Korea masih jauh di bawah tingkat memuaskan 7.0. Justifikasi untuk poin kedua ini adalah OPEN hanya diimplementasi khusus kota Seoul, dan belum terimplementasi untuk keseluruhan Korea Selatan. Selain itu, karena SMG telah mengeksekusi berbagai strategi anti-korupsi, peningkatan indeks anti korupsi tidak dapat sepenuhnya dikaitkan dengan sistem OPEN. Menurut (Kim et al., 2009) masyarakat, spesialis administrasi publik dan pegawai pemerintah memilih sistem OPEN kebijakan yang sangat berharga untuk pemerintah Seoul di tahun 1999 dan 2000. Sistem OPEN juga diakui oleh pemerintah international, pada tahun 2000 sekretaris jendral PBB Kofi Annan dan Koh, Walikota Seoul menyetujui untuk menawarkan sistem OPEN di 180 negara PBB. Pemerintah menyiapkan buku panduan untuk mengoperasikan OPEN dalam enam Bahasa, dan bersama-sama dengan PBB mengadakan anti-korupsi symposium di Seoul pada tahun 2001. Dengan undangan OECD sekretaris jendral, mengenalkan OPEN sebagai contoh sukses dari sebuah pendekatan inovatif untuk meningkatkan transparansi, menghalangi korupsi dan memberikan layanan lebih dekat ke pada masyarakat dalam admnistrasi public. Selain itu media termasuk "Business Week" (25 Juni 2001) dan (20 Agustus 2001) menampilkan sistem OPEN sebagai cara untuk mensterilkan pemerintah. Organisasi international dan World Bank mendorong negara-negara terkait untuk menggunakan sistem OPEN di beberapa negara, termasuk Vietnam, Indonesia, Bulgaria, Jepang, Cina, Mesir dan Nepal.

\subsection{Open Government Data di Brazil}

"Republik Federasi Brasil adalah negara terbesar di Selatan Amerika, dengan sekitar 190 juta dari penduduk tersebar di $8.514 .876 \mathrm{~km}$ 2. Brasil juga ekonomi pertama Selatan Amerika dan 7 dari dunia. Ibukotanya adalah Brasilia, terletak di pusat negara, tapi kota terbesar dan paling dinamis ekonomis adalah São Paulo, di Tenggara. Negara ini dibagi dalam 26 Serikat dan 5,565 kota, yang unit federatif - yang berarti mereka otonom dan memiliki Legislatif dan 
Eksekutif kekuatan mereka sendiri. Kota-kota menjadi otonom setelah Konstitusi 1988, yang menandai berakhirnya kediktatoran militer di negara itu, setelah 21 tahun. Ini menarik untuk dilihat selama desain konstitusi yang sama, Brazil mencoba untuk membangun sistem parlementer, tetapi penduduk, melalui plebisit diselenggarakan pada tahun 1993, memilih sistem pemerintahan Presidential" (Matheus et al., 2012). Pemanfaatan open data di Brazil termasuk dalam inisiatif E-Government pemerintah Brazil. Perkembangan e-government yang memanfaatkan teknologi informasi dan komunikasi di pemerintah yaitu dengan cara mengontrol keuangan dan pembayaran pajak. Namun, dengan skenario ini perlu adanya perubahan dari system lama yang telah dipergunakan selama ini. Salah satu fitur baru yang ditambahkan adalah sistem pemantauan anti-korupsi secara online. Ini adalah saluran baru di mana semua informasi tentang pemerintah dipublikasikan di portal transparansi dan adanya fitur untuk menerima pertanyaan dan keluhan oleh masyarakat dengan otoritas melalui Internet (Matheus et al., 2012).

Di Brazil e-Governance menurut (Matheus et al., 2012) adalah terkait dengan peningkatan kualitas, efisiensi, efektivitas, transparansi dan pengawasan dari badan pemerintah. Dengan ini menunjukkan bahwa e-governance dapat memenuhi ketersediaan informasi pemerintah. yaitu dengan cara universalisasi, penyediaan pelayanan publik, memberikan saluran informasi, tidak mengangu komunikasi antara daerah tertingal dengan administrasi pemerintah dan dengan keuntungan dari mempromosikan transparansi, terutama di area akuntansi pemerintah seperti yang terjadi pada portal dari "Federal Transparansi Pemerintah". E-governance dicirikan sebagai interaksi yang lebih luas dengan masyarakat, dan selalu berfokus pada layanan masyarakat dan membuat kita percaya dengan pengembangan e-domokrasi. Pemberantasan korupsi di Brasil telah menjadi terkenal melalui peningkatan pengawasan dari lembaga domestik pemerintah sebagai pengawas keuangan kantor administrasi umum dan audit pengadilan di seluruh Brasil. Meskipun evolusi pemberantasan korupsi dalam hal ini, menjelaskan bahwa partisipasi masyarakat adalah hal yang sangat penting untuk mengekang korupsi, konsep yang di percaya adalah dengan tidak ada kontrol sosial dan akuntabilitas, tidak ada yang dapat mengurangi korupsi secara maksimum, semua penyimpangan dan tindak korupsi di dalam negara Brazil (Matheus et al., 2012).

\begin{tabular}{|c|c|}
\hline Pros & Cons \\
\hline $\begin{array}{l}\text { Use of Geocoding: } \\
\text { Tracking public policies } \\
\text { and public works; } \\
\text { A Possibility to increase } \\
\text { transparency of data for social } \\
\text { control citizen } \\
\text { use ICT to promote citizen } \\
\text { participation: Extension of } \\
\text { models of tools aimed at helping } \\
\text { citizens' participation in external } \\
\text { control conducted by the SAS: } \\
\text { Although in its infancy, the } \\
\text { use of new social technologies } \\
\text { and multimodal to combat } \\
\text { comuption, such as: } \\
\text { i Web Radio; } \\
\text { Twitter; } \\
\text { SMS to complaints and } \\
\text { grievances; } \\
\text { Ombudsmen Online: } \\
\text { information; } \\
\text { Cadastral surveys of }\end{array}$ & $\begin{array}{l}\text { Database of } \\
\text { Online Tools Anti- } \\
\text { Comuption is incipient. Not } \\
\text { envision the integration of } \\
\text { information and } \\
\text { georeferencing of these data } \\
\text { are already collected by the } \\
\text { Courts of Auditors, as } \\
\text { studied in LRF and other } \\
\text { laws: Works and } \\
\text { services can be easily } \\
\text { cataloged (photos, files, } \\
\text { digital purchases and } \\
\text { procurement) and broadcast } \\
\text { channel does not exist for } \\
\text { this purpose, only the ECA } \\
\text { MT: Withdrawn use of } \\
\text { m technologies } \\
\text { mobile geep use } \\
\text { (although there is deep } \\
\text { of complaints, grievances } \\
\text { and so on. via text } \\
\text { messaging services and } \\
\text { video messages and images: }\end{array}$ \\
\hline
\end{tabular}


Tabel 3 Pro dan kontra system monitoring anti-korupsi di "State Court Account" di Brazil

\begin{tabular}{|c|c|}
\hline $\begin{array}{l}\text { municipalities and processes that } \\
\text { are being judged; } \\
\text { feedback regarding complaints; } \\
\text { about the tax situation before the } \\
\text { TBI of all municipalities in the } \\
\text { state; } \\
\text { Use of WEB TV online } \\
\text { TCEs } \\
\text { the National Council of Supreme } \\
\text { Audit: Standardization of plenary sessions of } \\
\text { decision making, evaluation and } \\
\text { trials of accounts and processes, } \\
\text { ultimately. who controls the } \\
\text { controllers? }\end{array}$ & $\begin{array}{l}\text { Poor use of social } \\
\text { technologies, such as } \\
\text { twitter, only the TEC has a } \\
\text { profile of Piaui in such } \\
\text { communication portal; } \\
\text { technology forums and } \\
\text { blogs online, with } \\
\text { discussion of controversial } \\
\text { issues and cases of raised } \\
\text { public interest, such as } \\
\text { complaints made by media } \\
\text { and so on; } \\
\text { electronic Infrequent use of } \\
\text { technologies, such as radio } \\
\text { web system, RSS 'feeds' and } \\
\text { also other technologies that } \\
\text { have already been } \\
\text { assimilated by society. }\end{array}$ \\
\hline
\end{tabular}

Namun, beberapa konsep pengembangan dari penggunaan system informasi oleh pemerintah Brazil, transparansi, partisipasi sipil dan untuk memerangi korupsi lingkupnya masih terbatas. Misalnya, dicatat dalam semua situs web bahwa gagasan transparansi hanya terbatas hanya untuk penilaian oleh masyarakat pada administrasi publik. Terlepas dari definisi Federal Konstitusi tentang beberapa undang-undang transparansi dalam pemerintah Brazil, gagasan, ide, data hanya sebatas iklan oleh pemerintah. Tidak ada tindakan menuju pengembangan infra-struktur atau bahkan pengunaan web 2.0 berikut langkah masyarakat sipil, seperti penggunaan jaringan sosial, blog dan lain-lain. Mayoritas dari sistem anti korupsi online menunjukkan bahwa ada tantangan lebih dari perspektif dalam kaitan yang direkomendasikan oleh studi pendahuluan atau literature review.

Meskipun beberapa perbaikan dalam penggunaan tertentu dari sistem Teknologi Internet menurut (Matheus et al., 2012) belum terlihat praktek intensif yang sudah diadopsi oleh masyarakat seperti media sosial (Twitter), blog dan forum diskusi pada situasi tertentu atau kasus yang muncul ke permukaan oleh perusahaan, penggunaan teknologi mobile, seperti mengirim teks pesan dan video dan gambar pesan (SMS dan MMS), dan penggunaan teknologi Web 2.0, meningkatkan interaksi antara warga dan pemerintah, yang disebut e-governance. Inisiatif untuk membuat porta transparansi muncul untuk menutupi konsep dari transparansi. Untuk menentukan tingkat transparansi dalam entitas publik yang berbeda dengan menggunakan e-government akan menarik untuk di kaji lebih dalam di masa depan untuk membangun alat penilaian untuk memeriksa kemungkinan peningkatan transparansi, yaitu pembangunan indeks yang mengukur tingkat yang berbeda dari transparansi yang ada di instansi pemerintah.Harus dikatalog fitur yang ada dan ditambahkan fitur-fitur yang mendukung untuk meningkatan transparansi dalam situs pemerintah.TIK, terutama internet, dapat meningkatkan kemungkinan peningkatan transparansi pelayanan pemerintah dalam proses dasar seperti pengadaan (e-procurement) dan penyaluran sumber daya fasilitas yang dapat diakses oleh siapa saja dan dimana saja. Manfaat peningkatan transparansi di ditampilkan, misalnya, promosi hak-hak kewarganegaraan, seperti hak untuk mengontrol sosial dari administrasi pemerintah.

Namun ada beberapa keterbatasan dari pengunaan "digital divide". Bahkan jika pemerintah membuat ketersediaan semua informasi situs pemerintah dengan jelas dan bisa diakses oleh perusahaan yang tidak memiliki akses ke teknologi atau area yang dibutuhkan, yang mempunyai kemampuan untuk memerangi koruspsi akan menjadi tidak berguna dan jalan untuk menuju ke masyarakat digital tidak akan tercapai atau hilang. Menurut VAV 2005 
dalam jurnal (Matheus et al., 2012) yaitu Informasi harus tersedia untuk masyarakat. Tidak hanya oleh ketentuan dalam undang-undang, yang memerlukan publisitas dari riwayat pemerintah, namun dengan memungkinkan partisipasi dan kontrol warga: "Partisipasi dan kontrol masyarakat sosial terhadap pemerintah tergantung pada arus informasi yang tersedia" VAV 2005. Masalah lain yang harus diatasi adalah isi dari informasi dan data yang harus selalu diperluas dan juga memiliki update secara konstan. Situs yang usang tidak bisa menawarkan kedalaman informasi dan masyarakat tidak dapat mengendalikan atau mengontrol administrasi pemerintah.

\section{KESIMPULAN}

Dari hasil pembahasan tentang Open Government Data sebagai inisiatif sistem antikorupsi di Indonesia: a cross-country comparison, ada beberapa hal yang dapat dijadikan pelajaran oleh Indonesia. Pertama, dengan penerapan system OPEN, pemerintah Korea Selatan berhasil membuat layanan mereka 85\% lebih transparan dan di tahun 2015 berdasarkan www.transparency.org Korea Selatan menduduki peringkat 37 dari 168 negara dan ini kesuksesan yang sangat signifikan. Kedua, karena sifatnya masih local, diperlukan adanya integrasi system dengan pemerintah pusat di Korea Selatan agar keuntungan yang didapat dengan penerapan OPEN lebih optimal. Ketiga, infrastruktur, khususnya telekomunikasi, berperan penting dalam penerapan monitoring system di Brazil. Terakhir, penerapan sistem anti-korupsi online akan berhasil jika pemerintah dan masyarakat saling bekerja sama dan informasi, data, layanan yang di berikan di portal harus update secara terus menerus.

Penelitian ini terbatas hanya mengambil sample dari penerapan system open data di dua negara, diperlukan penelitian lebih lanjut untuk dapat membandingkannya dengan insiatif open data di Indonesia, seperti dengan portal open data milik Pemerintah Pusat, Kementrian, Pemprov, dan Pemda. Dengan mempelajari hal-hal yang sudah dicapai oleh negara lain, diharapkan Indonesia dapat melakukan "leapfrog" dalam penerapan Open Government Data ini, sehingga keuntungan yang didapatkan dari penerapan teknologi ini menjadi lebih optimal ditambah dengan minimalnya resiko selama proses pembangunan system.

\section{DAFTAR RUJUKAN}

Anonim. (2015). Rekapitulasi Penindakan Pidana Korupsi di Indonesia. Retrieved from http://acch.kpk.go.id/statistik-tindak-pidana-korupsi

Badri, M. A., \& Alshareb, K. (2008). A path analytic model and measurement of the business value of e-government: An international perspective. International Journal of Information Management, 524-535.

Bramastyo, N. A. (2014). Laporan Audit Investigasi sebagai Bukti Permulaan Penyidikan Tindak Pidana Korupsi. Jurnal Hukum.

Dwivedi, Y. K., Ravishankar, M. N., \& Simintiras, A. C. (2015). Completing a PhD in business and management: A brief guide to doctoral students and universities. Journal of Enterprise Information Management.

Hardjaloka, L. (2014). Studi Penerapan e-Government di Indonesia dan NegaraLainnya Sebagai Solusi Pemberantasan Korupsi di Sektor Publik. Jurnal Rechts Vinding: Media Pembinaan Hukum Nasional, 435-452. 
ICW. (2013). Trend Pemberantasan Korupsi.

ICW. (2014). Trend Pemberantasan Korupsi 2014. Retrieved from Jakarta: Index, C. P. (2010). Transparency International.

Janssen, K. (2012). Open Government Data and the Right to Information: Opportunities and Obstacles. The Journal of Community Informatics, 8(2).

Janssen, M., Charalabidis, Y., \& Zuiderwijk, A. (2012). Benefits, Adoption Barriers and Myths of Open Data and Open Government. Information Systems Management.

Jetzek, T., Avital, M., \& Bjorn-Andersen, N. (2014). Data-Driven Innovation through Open Government Data. Journal of theoretical and applied electronic commerce research.

Kassen, M. (2013). A promising phenomenon of open data: A case study of the Chicago open data project. Government Information Quarterly, 508-513.

Komisi Pemberantasan Korupsi. (2006). Memahami Untuk Membasmi Buku Panduan untuk Memahami Tindak Pidana Korupsi. Jakarta: Perpustakaan Nasional: Katalog Dalam Terbitan (KDT).

Kurniawan, T. (2009). Peranan Akuntabilitas Publik dan Partisipasi Masyarakat dalam Pemberantasan Korupsi di Pemerintahan. Bisnis \& Birokrasi, Jurnal Ilmu Administrasi dan Organisasi, 16(2), 116-121.

Levy, Y. \& Ellis, T. (2006). A Systems Approach to Conduct an Effective Literature Review in Support of Information Systems Research. Informing Science.

Matheus, R., Ribeiro, M. M., Vaz, J. S., \& Souza, C. (2010). Using internet to promote the transparency and fight corruption: Latin American transparency portals. Proceedings of the 4th International Conference on Theory and Practice of Electronic Governance.

Matheus, R., Ribeiro, M. M., Vaz, J. S., \& Souza, C. (2012). Anti-corruption online monitoring systems in Brazil. Proceedings of the 6th International Conference on Theory and Practice of Electronic Governance.

Sadjiarto, A. (2000). Akuntabilitas dan Pengukuran Kinerja Pemerintahan. Jurnal Akuntansi dan Keuangan, 138 - 150. 
14 | JUSIFO (Jurnal Sistem Informasi), p-ISSN: 2460-092X, e-ISSN: 2623-1662 